\title{
Front Matter: Volume 6487
}

, "Front Matter: Volume 6487," Proc. SPIE 6487, Emerging Liquid Crystal Technologies II, 648701 (28 February 2007); doi: 10.1117/12.727569

SPIE Event: Integrated Optoelectronic Devices 2007, 2007, San Jose, California, SPIE. United States 


\title{
PROCEEDINGS OF SPIE
}

\section{Emerging Liquid Crystal Technologies II}

\author{
Liang-Chy Chien \\ Editor
}

21-22 and 24 January 2007

San Jose, California, USA

Sponsored and Published by

SPIE-The International Society for Optical Engineering

Volume 6487

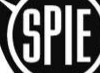

The International Society for Optical Engineering

Proceedings of SPIE-The International Society for Optical Engineering, 9780819466006, v. 6487

SPIE is an international technical society dedicated to advancing engineering and scientific applications of optical, photonic, imaging, electronic, and optoelectronic technologies. 
The papers included in this volume were part of the technical conference cited on the cover and title page. Papers were selected and subject to review by the editors and conference program committee. Some conference presentations may not be available for publication. The papers published in these proceedings reflect the work and thoughts of the authors and are published herein as submitted. The publisher is not responsible for the validity of the information or for any outcomes resulting from reliance thereon.

Please use the following format to cite material from this book:

Author(s), "Title of Paper," in Emerging Liquid Crystal Technologies II, edited by Liang-Chy Chien, Proceedings of SPIE Vol. 6487 (SPIE, Bellingham, WA, 2007) Article CID Number.

ISSN 0277-786X

ISBN 9780819466006

Published by

SPIE-The International Society for Optical Engineering

P.O. Box 10, Bellingham, Washington 98227-0010 USA

Telephone 1 360/676-3290 (Pacific Time) · Fax 1 360/647-1445

http://www.spie.org

Copyright @ 2007, The Society of Photo-Optical Instrumentation Engineers

Copying of material in this book for internal or personal use, or for the internal or personal use of specific clients, beyond the fair use provisions granted by the U.S. Copyright Law is authorized by SPIE subject to payment of copying fees. The Transactional Reporting Service base fee for this volume is $\$ 15.00$ per article (or portion thereof), which should be paid directly to the Copyright Clearance Center (CCC), 222 Rosewood Drive, Danvers, MA 01923. Payment may also be made electronically through CCC Online at http://www.copyright.com. Other copying for republication, resale, advertising or promotion, or any form of systematic or multiple reproduction of any material in this book is prohibited except with permission in writing from the publisher. The CCC fee code is 0277 $786 \times / 07 / \$ 15.00$.

Printed in the United States of America. 


\section{Contents}

vii Conference Committee

SESSION 1 PHOTONIC AND ELECTRO-OPTICS MATERIALS

648702 Optoelectronic and photonic properties of liquid crystals: electroluminescence and photorefractivity (Invited Paper) [6487-01]

S. A. Benning, M. W. Lauhof, L. Paelke, A. Redler, Univ. of Paderborn (Germany); F. Scheliga,

E. Thorn-Csanyi, V. Vill, Univ. of Hamburg (Germany); H.-S. Kitzerow, Univ. of Paderborn

(Germany)

\section{SESSION 2 TERAHERTZ APPLICATIONS}

648706 THz time-domain spectroscopy of liquid crystal colloids (Invited Paper) [6487-05]

M. Oh-e, H. Yokoyama, Japan Science and Technology Agency (Japan); M. Koeberg,

E. Hendry, M. Bonn, FOM Institute for Atomic and Molecular Physics (Netherlands)

648708 Effect of permanent dipole moments perpendicular to the molecular long axis on terahertz absorption in liquid crystals [6487-07]

S. Tanaka, Y. Okada, Tokyo Institute of Technology (Japan); K. Yamamoto, Osaka Univ. (Japan); Y. Takanishi, Tokyo Institute of Technology (Japan); M. Tani, Osaka Univ. (Japan); K. Ishikawa, Tokyo Institute of Technology (Japan); M. Hangyo, Osaka Univ. (Japan);

H. Takezoe, Tokyo Institute of Technology (Japan)

648709 Liquid-crystal-based electrically tunable THz optical devices (Invited Paper) [6487-08]

C.-L. Pan, R.-P. Pan, National Chiao Tung Univ. (Taiwan)

\section{SESSION 2 LASING}

64870B Tunable cholesteric liquid crystal lasers through in-plane switching [6487-10]

S. J. Woltman, G. P. Crawford, Brown Univ. (USA)

Pagination: Proceedings of SPIE follow an e-First publication model, with papers published first online and then in print and on CD-ROM. Papers are published as they are submitted and meet publication criteria. A unique, consistent, permanent citation identifier (CID) number is assigned to each article at the time of the first publication. Utilization of CIDs allows articles to be fully citable as soon they are published online, and connects the same identifier to all online, print, and electronic versions of the publication.

SPIE uses a six-digit CID article numbering system in which:

- The first four digits correspond to the SPIE volume number.

- The last two digits indicate publication order within the volume using a Base 36 numbering system employing both numerals and letters. These two-number sets start with 00, 01, 02, 03, 04, 05, 06, 07, 08, 09, 0A, OB ... 0Z, followed by 10-1Z, 20-2Z, etc.

The CID number appears on each page of the manuscript. The complete citation is used on the first page, and an abbreviated version on subsequent pages. 
64870C High efficient photonic band-edge cholesteric liquid crystal lasers [6487-11]

Y. Zhou, Y. Huang, Z. Ge, S.-T. Wu, College of Optics and Photonics, Univ. of Central Florida (USA)

64870D Large aperture laser beam attenuator using electro-optic gratings [6487-12]

S. Tang, Y. Tang, B. Duan, T. S. Hartwick, Crystal Research, Inc. (USA); J. Foshee, Air Force Research Lab. (USA)

64870E Spatial filter based on azo-dye-doped liquid crystal films (Invited Paper) [6487-19]

A. Y.-G. Fuh, T.-H. Lin, National Cheng Kung Univ. (Taiwan)

\section{SESSION $4 \quad$ LIQUID CRYSTAL ALIGNMENT}

64870F Liquid crystal photoalignment: history and future (Invited Paper) [6487-13]

V. G. Chigrinov, H. S. Kwok, Hong Kong Univ. of Science and Technology (Hong Kong

China); H. Takada, H. Takatsu, Dainippon Ink and Chemicals, Inc. (Japan)

64870 Lyotropic chromonic liquid crystals as materials for optical and biosensing applications (Invited Paper) [6487-16]

L. Tortora, H.-S. Park, K. Antion, D. Finotello, O. D. Lavrentovich, Kent State Univ. (USA)

\section{SESSION 5 FLEXIBLE DISPLAYS}

64870J New developments in flexible cholesteric liquid crystal displays (Invited Paper) [6487-17] T. Schneider, D. J. Davis, S. Franklin, N. Venkataraman, D. McDaniel, F. Nicholson,

E. Montbach, A. Khan, J. W. Doane, Kent Displays, Inc. (USA)

64870L Development of polymer cholesteric liquid crystal flake technology for electro-optic devices and particle displays (Invited Paper) [6487-34]

T. Z. Kosc, K. L. Marshall, A. Trajkovska-Petkoska, C. J. Coon, K. Hasman, G. V. Babcock, R. Howe, M. Leitch, Univ. of Rochester (USA); S. D. Jacobs, Univ. of Rochester (USA) and Institute of Optics, Univ. of Rochester (USA)

$64870 \mathrm{M} \quad$ Bimesogenic liquid crystals: new materials for high-performance photonics devices and displays (Invited Paper) [6487-35]

H. J. Coles, Univ. of Cambridge (United Kingdom)

\section{SESSION 6 LENS, MIRRORS, AND WAVEGUIDES}

64870N Development of high quality liquid crystal lens (Invited Paper) [6487-20]

M. Ye, B. Wang, S. Sato, Akita Univ. (Japan)

648700 Wave guiding with liquid crystals (Invited Paper) [6487-21]

K. Neyts, J. Beeckman, H. Desmet, Ghent Univ. (Belgium)

64870P Electrically switchable mirrors based on polymer-stabilized cholesteric liquid crystals [6487-22]

S.-Y. LU, A. Golovin, L.-C. Chien, Kent State Univ. (USA) 
64870R Nematic liquid crystal cells for optical spatial solitons (nematicons) (Invited Paper) [6487-24]

A. De Luca, A. Veltri, L. Pezzi, G. Coschignano, C. Umeton, INFM-CNR (Italy) and Univ. of Calabria (Italy); A. Alberucci, C. Conti, M. Peccianti, G. Assanto, Univ. Roma Tre (Italy) and INFM-CNR (Italy)

\section{SESSION 7 IMAGING, TWEEZING, AND ELECTRO-OPTICS OF NANOPARTICLE DISPERSIONS}

64870T Applications of ferroelectric particles/liquid crystal colloids (Invited Paper) [6487-26] A. Glushchenko, Univ. of Colorado at Colorado Springs (USA); C. I. Cheon, Hoseo Univ. (South Korea); J. West, Kent State Univ. (USA); Y. Reznikov, Institute of Physics (Ukraine)

$64870 U$ Effects of carbon nanotubes on physical properties of nematic liquid crystal and liquid crystal device (Invited Paper) [6487-27]

S. H. Lee, Chonbuk National Univ. (South Korea); H.-K. Lee, S.-E. Lee, Merck Advanced

Technologies, Ltd. (South Korea); Y. H. Lee, Sungkyunkwan Univ. (South Korea)

\section{SESSION 8 GRATING AND SPATIAL LIGHT MODULATORS}

$64870 \mathrm{~V}$ Liquid crystal Bragg gratings: dynamic optical elements for spatial light modulators (Invited Paper) [6487-28]

R. L. Sutherland, V. P. Tondiglia, L. V. Natarajan, Air Force Research Lab. (USA) and Science Applications International Corp. (USA); J. M. Wofford, Air Force Research Lab. (USA);

S. A. Siwecki, Air Force Research Lab. (USA) and Science Applications International Corp. (USA); G. Cook, Air Force Research Lab. (USA) and Universal Technology Corp. (USA);

D. R. Evans, Air Force Research Lab. (USA); P. F. Lloyd, Air Force Research Lab. (USA) and UES, Inc. (USA); T. J. Bunning, Air Force Research Lab. (USA)

64870X New HDTV $(1920 \times 1080)$ phase-only SLM [6487-30]

S. Osten, S. Krüger, A. Hermerschmidt, HoloEye Photonics AG (Germany)

$64870 Y$ LCOS spatial light modulator controlled by 12-bit signals for optical phase-only modulation [6487-31]

T. Inove, H. Tanaka, N. Fukuchi, M. Takumi, N. Matsumoto, T. Hara, N. Yoshida, Y. Igasaki,

Y. Kobayashi, Hamamatsu Photonics K. K. (Japan)

\section{POSTER SESSION}

$64870 Z$ Multiple-functional and cost-effective liquid-crystal cell parameter measurement system [6487-32]

G.-W. Chang, Y.-H. Lin, Z.-M. Yeh, National Taiwan Normal Univ. (Taiwan)

648710 Spatial optical modulator (SOM): high-density diffractive laser projection display [6487-33]

S. Yun, J. Song, I. Yeo, Y. Choi, V. Yurlov, S. An, H. Park, H. Yang, Y. Lee, K. Han, I. Shyshkin,

A. Lapchuk, K. Oh, S. Ryu, J. Jang, C. Park, C. Kim, S. Kim, E. Kim, K. Woo, J. Yang, E. Kim,

J. Kim, S. Byun, S. Lee, O. Lim, J. Cheong, Y. Hwang, G. Byun, J. Kyoung, S. Yoon, J. Lee,

T. Lee, S. Hong, Y. Hong, D. Park, J. Kang, W. Shin, S. Lee, S. Oh, B. Song, H. Kim, C. Koh,

Y. Ryu, H. Lee, Y. Baek, Samsung Electro Mechanics Co. Ltd (South Korea)

Author Index 
Downloaded From: https://www.spiedigitallibrary.org/conference-proceedings-of-spie on 26 Apr 2023

Terms of Use: https://www.spiedigitallibrary.org/terms-of-use 


\title{
Conference Committee
}

\author{
Symposium Chair \\ Yakov Sidorin, Photineer Technology Group (USA) \\ Symposium Cochair
}

Ali Adibi, Georgia Institute of Technology (USA)

Program Track Chairs

Liang-Chy Chien, Kent State University (USA)

Ming H. Wu, Hamamtsu Corporation (USA)

Conference Chair

Liang-Chy Chien, Kent State University (USA)

Program Committee

Dick J. Broer, Technische Universiteit Eindhoven (Netherlands)

Harry J. Coles, University of Cambridge (United Kingdom)

Gregory P. Crawford, Brown University (USA)

Andy Ying-Guey Fuh, National Cheng Kung University (Taiwan)

Wolfgang Haase, Technische Universität Darmstadt (Germany)

Jun-ichi Hanna III, Tokyo Institute of Technology (Japan)

Shunsuke Kobayashi, Tokyo University of Science (Japan)

Akihiro Mochizuki, Nano Loa Inc. (USA)

Ci-Ling Pan, National Chiao Tung University (Taiwan)

Shin-Tson Wu, College of Optics and Photonics, University of Central Florida (USA)

\section{Session Chairs}

$1 \quad$ Photonic and Electro-Optics Materials

Liang-Chy Chien, Kent State University (USA)

2 Terahertz Applications

Vladimir G. Chigrinov, Hong Kong University of Science and Technology

(Hong Kong China)

3 Lasing

Iam Choon Khoo, The Pennsylvania State University (USA)

$4 \quad$ Liquid Crystal Alignment

Tod L. Schneider, Kent Displays, Inc. (USA) 
$5 \quad$ Flexible Displays

Cees W. M. Bastiaansen, Technische Universiteit Eindhoven (Netherlands)

6 Lens, Mirrors, and Waveguides

Shin-Tson Wu, College of Optics and Photonics, University of Central Florida (USA)

$7 \quad$ Imaging, Tweezing, and Electro-Optics of Nanoparticle Dispersions

Oleg D. Lavrentovich, Kent State University (USA)

$8 \quad$ Grating and Spatial Light Modulators

Andy Ying-Guey Fuh, National Cheng Kung University (Taiwan) 